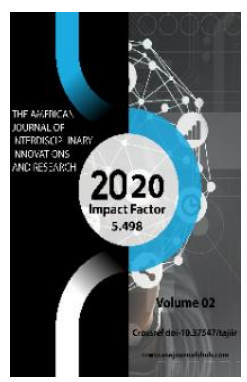

\title{
Lithographs Of Alisher Nava'i's Works Kept In The Museum Of Literature
}

\author{
Shafoat Khasanova \\ Doctor Of Philological Sciences, State Museum Of Literature Of The Academy Of Sciences Of \\ The Republic Of Uzbekistan
}

\begin{abstract}
Journal Website: http://usajournalshub.c om/index,php/tajiir

Copyright: Original content from this work may be used under the terms of the creative commons attributes 4.0 licence.
\end{abstract}

\section{ABSTRACT}

Fund of manuscripts of the State Museum of Literature. Alisher Nava'i of the Academy of Sciences of the Republic of Uzbekistan contains many ancient sources and lithographs. Today, a number of our scientists are working on the creation of an electronic catalog of lithographs kept in the museum, and preparation for publication. Most of the lithographs are works of Nava'i. The article scientifically describes 8 lithographs of works by Alisher Nava'i, stored in the State Museum of Literature of the Academy of Sciences of the Republic of Uzbekistan. This article was written within the framework of the grant "Creation and preparation for publication of an electronic catalog of lithographs stored in the State Museum of Literature named after Alisher Nava'i". The descriptions of the grant participants M. Rashidova and O. Alimov were used.

\section{KEYWORDS}

Alisher Nava'i, lithograph, publisher, copy, scientific description, text, table, typography, Diwan, cover.

\section{INTRODUCTION}

Thousands of ancient written monuments that replenish the treasures of the world reflect the past culture of each nation. They contain a lot of information about the rich spiritual and cultural heritage of the people, ancient traditions and beliefs. The study of the rich cultural heritage left by our ancestors, its transfer to future generations remains an important problem not only in our country, but also in the eyes of scientists around the world. The President's decree "On measures to further improve the system of preservation, 
research and popularization of ancient written sources" forms a new stage in the study of our written monuments. [1. 1] According to the resolution, "monitoring the state of preservation and repair of manuscripts, lithographs and historical documents in Arabic script stored in various organizations of the Republic of Uzbekistan and the creation of their electronic database" is one of the urgent tasks today.

\section{MATERIALS \& METHODS}

The manuscript collection of the State Literary Museum named after Alisher Nava'i of the Academy of Sciences of the Republic of Uzbekistan also contains many ancient sources and lithographic works. Currently, the museum is working on a scientific project PD20170920167 "Creation and preparation for publication of an electronic catalog of lithographs stored in the State Literary Museum named after Alisher Nava'i" for 20182020. This research will be prepared in Uzbek and will be available to the general scientific community through the museum's website. It includes descriptions of 500 lithographic works in Arabic, Persian and Turkish, divided into languages and themes. The main task of the article is to give a scientific description of the lithographic editions of Alisher Nava'i's works. This serves as a source for source scholars, textologists, literary critics, orientalists and the general public interested in the written monuments preserved in the manuscript collections of our country.

Descriptive, comparative-historical, systematic and statistical methods were widely used to cover the topic of the article.

\section{RESULTS \& DISCUSSION}

The museum has kept about 1,500 lithographs. Among them, the works of Hazrat Alisher Nava'i occupy a significant place. Out of a total of 72 lithographs of Nava'i's works kept in the fund, 21 are photocopies from rare manuscripts.

The lithograph number 769 consists of the work "Muhokamat ul-lug'atayn". Written by the publisher himself. A work of discussion of Persian with Turkish language. In it, the richness of the Turkic language proves that while a word is used in the Persian language to express different levels of meaning compared to the Persian language, there is a separate word in the Turkish language to express each level.

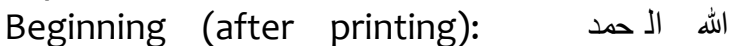

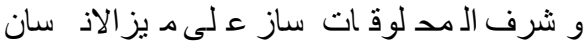

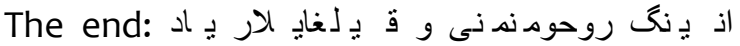

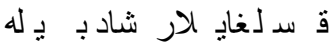

A preface is given before starting work. 3 pages. It contains information about the life and work of Alisher Nava'i from "Qomusi A'lam".

The text is printed in black ink, without a table, on the sketch, 20 lines per page, in the average Nasta'liq letter. Pages are numbered. The book is the second edition and was published in Kokand by II Voynir Porovoy. 1916y. December 20.

Cardboard cover glued to plain unadorned paper with a dark brown tint.

Disadvantage: The text is copied from the cover, pasted on a newspaper sheet. The last pages have inked areas. 41 pages. Size: $13 \times 20.5$ $\mathrm{cm}$.

Among the lithographs of the works of Hazrat Nava'i, his devons are very common. Several of them are on display.

The copy on display No. 111 is called "Diwani Mavlono Amir Nava'i". A collection of poems by Alisher Nava'i "C'aroyib us-sig'ar".

The text is written in two columns in the form of a Nasta'liq letter (1324 AH).

Beginning (after printing):

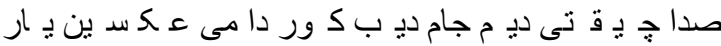

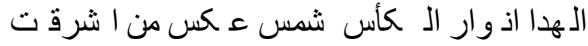

The end:

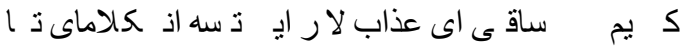

$$
\begin{aligned}
& \text { ساق ى اى خر اب اولـ سه سـ ست حـ شردا }
\end{aligned}
$$


The title page and the last page are "Jubilee Library". Committee Nava’i № 316 ", “Institute of Manuscripts Printed Books № 111 "and" Manuscript Fund of Nava'i Museum of Literature - inv. 111 "are sealed.

Cardboard cover glued to paper with a picture of simple patterns. On the cover there are papers with the inscription "111" G'aroyib ussig'ar "Diwani 316" in Arabic script.

Book مححد بـ بك بـ ن ظ فر مل Printed by Mullo Zafar bin Bek Muhammad at the "V.M.Ilin" printing house in Tashkent.

Pink colored cardboard cover. 144 pages (1144). Size: $14 \times 23 \mathrm{~cm}$.

Another national cabinet on display is stored under inventory number 47. The collection of poems by Alisher Nava'i was published in 1900 in Tashkent. 166 pages.

The text is written in two columns in the form of a Nasta'liq letter.

Beginning (after printing):

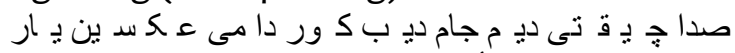

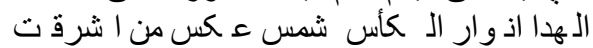

The end:

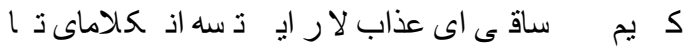

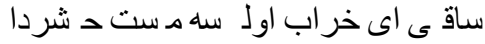

The title page has the stamps "Library Jubilee Committee Nava'i - 125 k" and "Manuscript Fund of the Nava'i Museum of Literature - inv 47". Printed in 1900 by the Turkestan Military District Printing House in Tashkent. Modern faux leather cover in black. Dimensions: $14.5 \times 23 \mathrm{~cm}$.

Nava'i Diwan No. 116 is also on display. This lithograph begins with the verse, "O navbahor orazing subhiga janparvar havo."

The text is copied into the table in 2 columns in the sample of the Nasta'liq letter.

Beginning:

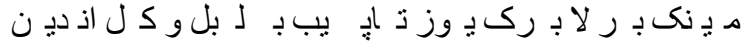

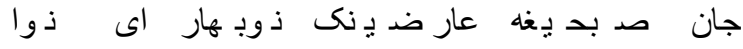

$$
\begin{aligned}
& \text { هو ابـ برور }
\end{aligned}
$$

The end:

$$
\text { ك رمهو ذ عال ى الله بـ عون ذ مت }
$$

The title page has the stamps "Library Jubilee Committee Nava'i" and "Manuscript Fund of the Nava'i Museum of Literature - inv 116". Printed by Turkestanskiy Kuryer printing house in Tashkent. Cardboard cover glued to paper with a picture of simple patterns. On the cover there is an Arabic spelling " 116 Diwani Amir Alisher Nava'i 336" and "EU. 192 inv № 2 ". Inside the cover are two pages of another printed book. Disadvantage: the book is separated from the cover. 167 pages. Size: $17 \times 27 \mathrm{~cm}$.

Diwan No. 46 consists of ghazals, tarjiband, muqatta'at, mufradots of Nava'i. Diwan begins with the following ghazal of "Badoyi ulvasat" (Middle Ages).

Beginning (after printing):

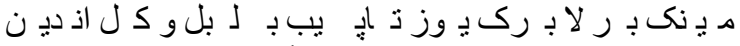

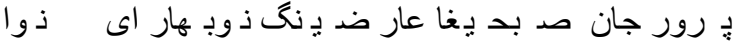

$$
\begin{aligned}
& \text { Is }
\end{aligned}
$$

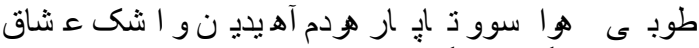

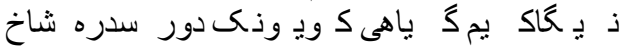

The end:

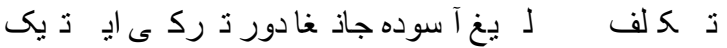

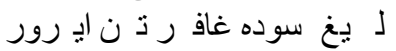

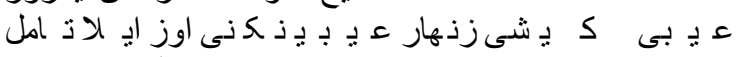

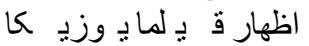

The text is written in 2 columns in the example of the Nasta'liq letter.

At the end of the book, in the "Hatimat uttab" section, the name of the secretary, the date and place of copying are mentioned. Kotib - اوغ لى ذ عمت شاه ملا مر اد شاه Shah Murad Mullo Shah Ne'mat oglu, Time and place of relocation - 29th day of Ramadan, $1304 \mathrm{AH}$, Tashkent.

The title page and the last page contain "Institute of Manuscripts - Printed Books 46" and "Manuscript Fund of Nava'i Museum of Literature inv. № 46 "are available. Rahimhoja eshan ibn Alikhoja eshan was probably published in Lakhtin printing house in Tashkent in $1304 \mathrm{AH}$ in the month of Rabi 'alAwwal. Pumpkin-colored three-letter 
cardboard cover.

Disadvantage: The cover is damaged, the cover is detached from the book, the pages are scattered, torn. 288 pages. Dimensions: $17 \times 26.5 \mathrm{~cm}$.

Another copy of Hazrat Nava'i's office is kept under number 164. The secretary is the son of Shohmurod Mullo Shohne'mat.

Publisher: اي شان عـل يخو اجه اب ن اي شان رح يمخو اجه Rahimhoja eshan ibn Alihoja eshan.

Diwan is composed of ghazals, masnavi, rubai and fards.

Beginning:

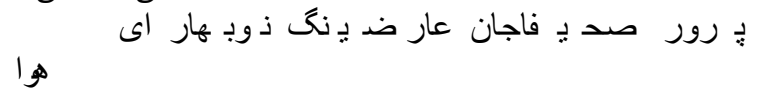

The end:

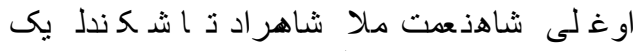

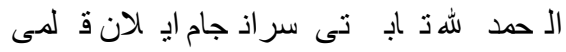

The text is written in black ink in 15 rows, two columns into a table. Pages are numbered.

The book was published by Loxtin in 1884 . 1334 h. printed in the month of "Robe "ulAwwal".

Black leather coated cardboard cover.

Disadvantage: The book is separated from the cover, page 1 is separate. The edges of the pages are broken. 277 pages. Dimensions: $16.5 \times 26.5 \mathrm{~cm}$.

Alisher Nava'i's “G'aroyib us-sig'ar" office was published in lithography number 97. The text is written into a table in the form of two columns in the sample of the Nasta'liq letter. Beginning (after printing):

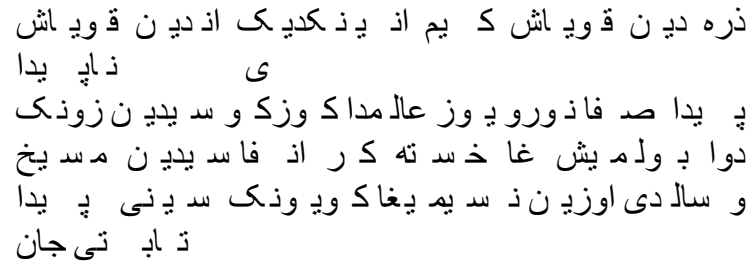

The end:

$$
\begin{aligned}
& \text { ق طعه }
\end{aligned}
$$

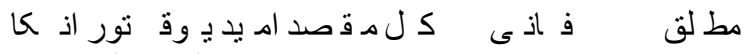

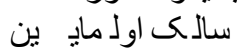

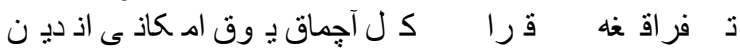

$$
\begin{aligned}
& \text { قو طره سد بـ نمايد بين }
\end{aligned}
$$

$$
\begin{aligned}
& 1329 \text { سدنة فـى الـ هلب الــ لك بـ عون الـ كـ تاب تمّت }
\end{aligned}
$$

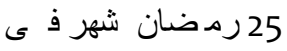

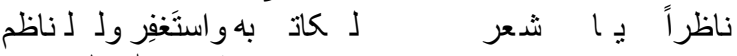

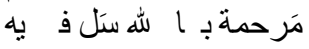

In the upper right corner of the Kokand silk adventure is a small piece of paper with the Arabic spelling " 97 "C'aroyib us-sig'ar" 256 ".

On pages 3 and 128, "Manuscript Fund of the Nava'i Museum of Literature inv. № 97 ",“ Institute of Manuscripts - Printed Books 97 "and" Jubilee Library. Committee Nava'i № $256 "$.

Black artificial leather coated cardboard cover. Disadvantage: the book has no beginning. 126 pages. Dimensions: $17.5 \times 26.5 \mathrm{~cm}$.

Another 22-volume collection of poems "G'aroyib us-sig'ar" is on display.

Among the lithographs of Alisher Nava'i's works, in addition to the diwans, there are 3 copies of Abdurahmon Jami and Alisher Nava'i's "Chihil Hadith" in Persian and Turkish languages. These copies are kept under numbers 59, 227 and 837.

Copy No. 59 Mawlawi بامى الرحمن ع بد Abdurahman Jami's "Chihl Hadith" is a Persian and ذوائى على يـ شد ير Alisher Nava'i’s Turkish translation. It quotes four hadith-based quatrains side by side in Persian and Turkish.

The text is copied into the table in 2 columns in the sample of the Nasta'liq letter. In the first half of the column there is Jami, in the second half there is Nava'i's interpretation.

Beginning (after printing):

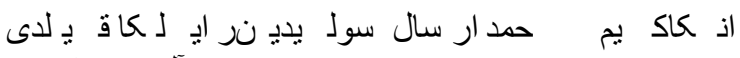

$$
\begin{aligned}
& \text { مآل خ بر ك لاد لام }
\end{aligned}
$$

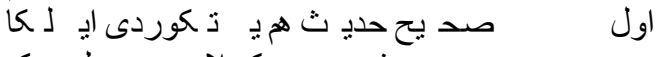

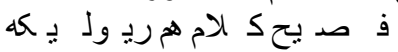

The end:

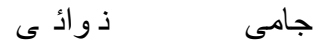

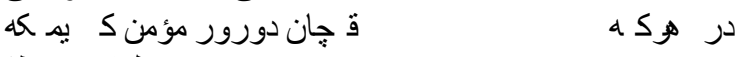

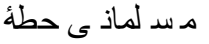

$$
\begin{aligned}
& \text { آج بـ ول غاى قوذ شى و د وق اوزهك يم يم }
\end{aligned}
$$




$$
\begin{aligned}
& \text { ك ر راذ ماي هـ ند قددي ن از بـ الشد }
\end{aligned}
$$

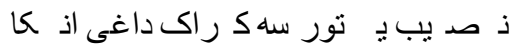

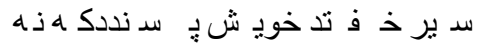

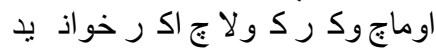

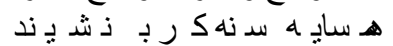

Title and last page "Institute of Manuscripts Printed Books 59", "Manuscript Fund of Nava'i Museum of Literature inv. № 59 "are available. Surat al-Fatihah of the Holy Quran is attached to the end of the book. Then page 23 was added again.

The publisher and editor of the newspaper

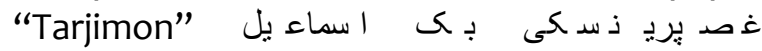
Ismailbek Gaspirinsky in the Garden Palace (Turkey) from 1309 to $1907 \mathrm{~m}$. printed in.

\section{CONCLUSION}

During these years, not only the works of poets and writers, but also manuscripts and lithographs on history, Islamic philosophy, mysticism, medicine, geography, astronomy, linguistics and other fields of science occupy a worthy place in the museum fund. They are periodically displayed in the exhibition halls of the museum, arousing the audience's sense of pride in the spiritual wealth created by our people, as well as attracting the attention of domestic and foreign scholars.

\section{REFERENCES}

1. Resolution of the President of the Republic of Uzbekistan "On measures to further improve the system of preservation, research and promotion of ancient manuscripts" // "People's Word" newspaper, 2017. May 25, №103 (6797), p. 1. 